\title{
Streptococcus raffinolactis Orla-Jensen and Hansen, a Group N Streptococcus Found in Raw Milk
}

\author{
ELLEN I. GARVIE \\ National Institute for Research in Dairying, Shinfield, Reading, England
}

\begin{abstract}
The properties of the lactate dehydrogenases, percent guanine plus cytosine in the deoxyribonucleic acid (DNA), and DNA/DNA hybridization studies have shown that three strains of group N streptococci do not belong to either Streptococcus lactis or Streptococcus cremoris. The biochemical properties of the three strains were published about 25 years ago, and at that time the strains were not assigned to any species. The three strains are here identified as members of Streptococcus raffinolactis Orla-Jensen and Hansen.
\end{abstract}

Orla-Jensen and Hansen (11) studied the bacteriological flora of spontaneously soured milk and commercial butter starters. Besides Streptococcus lactis and Streptococcus cremoris, they named four other species among their isolates. These species have been largely overlooked since the original publication. However, Garvie (3) described some raw-milk group N streptococci which fermented raffinose and which were similar to strains of Streptococcus raffinolactis Orla-Jensen and Hansen. Swartling (12) included three of Garvie's strains in his work and was of the opinion that they were neither $S$. lactis nor $S$. cremoris. In the early 1950 s it was felt that not enough was known about the strains to justify calling them $S$. raffinolactis as it was possible that they might prove to be subspecies of either S. lactis or $S$. cremoris.

Three of the strains isolated by Garvie were freeze-dried and kept in the National Collection of Dairy Organisms (NCDO). Recently they were examined for additional properties, and the results of these studies have shown that they belong to neither $S$. lactis nor $S$. cremoris.

\section{MATERIALS AND METHODS}

Strains. All of the strains studied are in the National Collection of Dairy Organisms. S. raffinolactis NCDO 617 (23.C.5), NCDO 618 (30.C.1), and NCDO 619 (33.C.1) were compared with S. lactis NCDO 712 and NCDO 2031, S. lactis subsp. diacetylactis NCDO 1007 , and S. cremoris NCDO 924.

Cultures were grown in a yeast-glucose-phosphate broth (YGPB) containing (weight/volume): peptone (Oxoid), 1.0\%; Lemco (Oxoid), 0.8\%; glucose, 1.0\%; $\mathrm{NaCl}, 0.5 \%$; yeast extract (Oxoid), $0.3 \% ; \mathrm{KH}_{2} \mathrm{PO}_{4}$, $0.15 \% ; \mathrm{MgSO}_{4} \cdot 7 \mathrm{H}_{2} \mathrm{O}, 0.02 \% ; \mathrm{MnSO}_{4} \cdot 4 \mathrm{H}_{2} \mathrm{O}, 0.005 \% ; \mathrm{pH}$ 6.8 .

All cultures were incubated at $30^{\circ} \mathrm{C}$.

Preparation of lactate dehydrogenase (LDH) in cell extracts. Cultures were grown overnight at $30^{\circ} \mathrm{C}$ in YGPB. Cells were removed by centrifuging and were washed twice at $4^{\circ} \mathrm{C}$ with $0.85 \% \mathrm{NaCl}$. Cell pellets were quick-frozen in $\mathrm{CO}_{2}$ and stored, at least overnight, at $-18^{\circ} \mathrm{C}$. When cells were required, a chilled solution containing $0.425 \% \mathrm{NaCl}$ in $0.01 \mathrm{M}$ phosphate ( $\mathrm{pH} 7.0$ ) was added to the tube containing the frozen pellet; this material was kept at $4^{\circ} \mathrm{C}$ until the pellet was thawed. Approximately $5.0 \mathrm{ml}$ of chilled solution was used for 0.5 to $0.7 \mathrm{~g}$ of wet-packed cells. The cell suspension was transferred to a 10-ml Kimex tube, and Ballotini beads $(0.115$ to $0.180 \mathrm{~mm}$ in diameter) were added to fill the tube to about $1 \mathrm{~cm}$ below the shoulder. The cells were broken on a Braun homogenizer for 6 min while kept cold with 2- to 3-s blasts of $\mathrm{CO}_{2}$ every $30 \mathrm{~s}$. After the cells were broken, the liquid was removed and the glass beads were washed three times with $3.0 \mathrm{ml}$ of the sodium chloridephosphate solution. The washings were added to the supernatant. Glass beads and cell debris were precipitated by centrifuging at $36,000 \times g$ for $45 \mathrm{~min}$ at $4^{\circ} \mathrm{C}$.

The supernatant was dialyzed against $0.0425 \% \mathrm{NaCl}$ in $0.01 \mathrm{M}$ phosphate at $\mathrm{pH} 7.0$, and the resulting liquid was freeze-dried and stored in a deep freeze.

For use, the freeze-dried material was dissolved in $0.01 \mathrm{M}$ phosphate buffer ( $\mathrm{pH} 7.0$ ). Usually a concentration of $10 \mathrm{mg}$ of freeze-dried powder per $\mathrm{ml}$ gave an active preparation.

Estimation of activity. LDH activity was assayed by following the decrease in absorption at $340 \mathrm{~nm}$ on a Unicam SP1700 spectrophotometer with a Philips $\mathrm{XY}$ recorder adjusted so that the $x$ axis recorded time. A $0.02-\mathrm{ml}$ volume of enzyme solution was added to 1.0 $\mathrm{ml}$ of assay solution to start the reaction. The assay solution contained $0.067 \mathrm{mM}$ tris(hydroxymethyl)aminomethane (Tris)-chloride buffer ( $\mathrm{pH} 7.0$ ) or $0.067 \mathrm{mM}$ acetate buffer (pH 5.5) and $0.15 \mu \mathrm{M}$ reduced nicotinamide adenine dinucleotide (NADH), The standard assay also contained $3.3 \mathrm{mM}$ sodium pyruvate, $0.5 \mathrm{mM}$ fructose 1,6-diphosphate (FDP), and no additional phosphate. When variations in these concentrations were used, they are shown in the tables. The decrease in optical density in 1 min was recorded. All reactions were done at $30^{\circ} \mathrm{C}$.

Electrophoresis of LDH. The composition of the gels was as given previously (4) except that cylindrical gels were prepared wtih $0.2 \mathrm{M}$ Tris-phosphate buffer (pH 7.0) (final concentration in the gel was $0.05 \mathrm{mM}$ ). A Quickfit electrophoresis module was used with 0.05 
M Tris-phosphate buffer (pH 7.0) as tank buffer. The buffer surrounding the gel tubes was cooled by running tap water. Gels were developed in $0.1 \mathrm{M}$ Tris-chloride buffer ( $\mathrm{pH} \mathrm{7.0)}$ or $0.1 \mathrm{M}$ acetate buffer ( $\mathrm{pH} 5.5$ ), containing (weight per volume per milliliter): sodium pyruvate, $2.75 \mathrm{mg}$; sodium FDP, $0.4 \mathrm{mg}$; NADH, 1.0 mg. After $30 \mathrm{~min}$ of incubation at $30^{\circ} \mathrm{C}$ the gels were stained in a solution containing (weight per volume per milliliter): nitroblue tetrazolium, $0.5 \mathrm{mg}$; phenazine methosulfate, $0.05 \mathrm{mg}$, in $0.1 \mathrm{M}$ Tris-chloride buffer (pH 8.1) (4).

Preparation of DNA. Cultures were grown in YGPB, cells were harvested, and deoxyribonucleic acid (DNA) was purified as described by Garvie (5). The melting curves of the DNA dissolved in standard saline citrate (8) were followed by using a Unicam SP1700 spectrophotometer with an SP876 (Mark 2) temperature program and Phillips XY recorder.

DNA/DNA hybridization studies. The relationship of $S$. raffinolactis to other serological group $\mathrm{N}$ streptococci was estimated by DNA renaturation rates according to the method of De Ley et al. (2). DNA was sheared before denaturation by passing it 10 times through a 1-inch (ca. 2.54-cm), 26-gauge syringe needle. Renaturation was done at $65^{\circ} \mathrm{C}$, and the change in optical density was followed on a Unicam SP1700 spectrophotometer with an AR55 recorder attached.

Phenotypic characteristics. The strains were checked by the technique described in 1953 by Garvie (3) for a number of the properties previously described.

\section{RESULTS AND DISCUSSION}

The melting temperatures of the DNA of $S$. raffinolactis were found to be 1.5 to $2^{\circ} \mathrm{C}$ higher than those of strains of either $S$. lactis or $S$. cremoris (Table 1). It follows that there is a difference of 4 to $6 \%$ between the guanine-pluscytosine $(\mathrm{G}+\mathrm{C})$ content of the DNA of $S$. raffinolactis and that of the DNA of other group $\mathrm{N}$ streptococci. This difference is indicative of a species distinction (10).

A second property considered to be of significance concerned the LDHs of $S$. raffinolactis. On electrophoresis this enzyme activity was detected in two distinct bands. The slower-moving band of activity travelled the same distance as the single LDH detected in preparations of $S$. lactis (Fig. 1). Gels of the LDH of $S$. cremoris were indistinguishable from those of $S$. lactis LDH.

The LDHs of strains NCDO 617, NCDO 618, and NCDO 619 were examined several times. The cell extracts were found to remain stable for up to 2 years. The LDH patterns of the three strains were not identical (Fig. 1). In the original gels two areas of activity were detected visually in extracts of NCDO 618, and of these the slower was very faint and did not reproduce. The fastermoving component in NCDO 618 was always more distinct than either component in extracts
TABLE 1. Percent guanine plus cytosine $(\% G+C)$ in the DNA of some group $N$ streptococci

\begin{tabular}{lccc}
\hline \multicolumn{1}{c}{ Species } & $\begin{array}{c}\text { NCDO } \\
\text { no. }\end{array}$ & $\begin{array}{c}T_{m} \\
\left({ }^{\circ} \mathrm{C}\right)\end{array}$ & $\begin{array}{c}\% \\
\mathrm{G}^{2} \mathrm{C}^{a}\end{array}$ \\
\hline S. raffinolactis & 617 & 87.4 & 41.5 \\
& 618 & 87.4 & 41.5 \\
& 619 & 86.9 & 40.3 \\
S. lactis & & & \\
$\quad$ C2 (Lac $\left.{ }^{+}\right)$ & 2031 & 85.3 & 36.3 \\
$\quad$ C2 (Lac) & & 85.4 & 36.7 \\
S. cremoris & & & \\
$\quad$ Fast variant & 924 & 84.7 & 34.9 \\
$\quad$ Slow variant & & 84.9 & 35.4 \\
L. mesenteroides 39 & 768 & 86.6 & 39.6 \\
E. coli K-12 & 1984 & 91.75 & 52.1 \\
\hline
\end{tabular}

${ }^{a} \% \mathrm{G}+\mathrm{C}=\left[\left(T_{m}-70.4\right) 2.44\right]$. Since the melting temperature $\left(T_{m}\right)$ of strains 39 and $\mathrm{K}-12$ measured in this laboratory are consistently $1^{\circ} \mathrm{C}$ higher than the figures given by Marmur and Doty (9) and De Ley (1) for these same strains, the formula used for calculating $\% \mathrm{G}+\mathrm{C}$ from $T_{m}$ has been modified to take account of this experimental difference between laboratories.

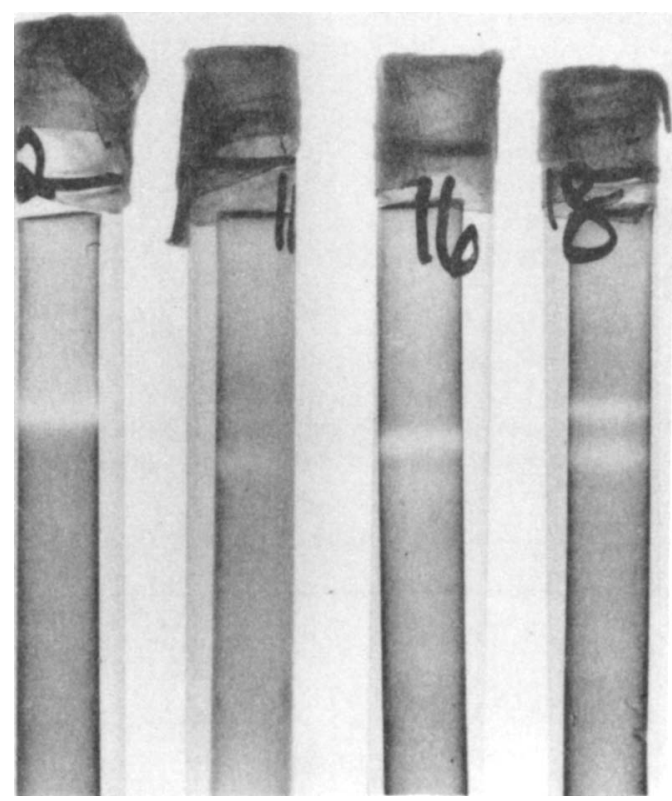

FIG.'1. Electrophoresis gels showing the LDHs of four strains of streptococci. Left to right: $S$. lactis NCDO 712 , S. raffinolactis NCDO 617, NCDO 618, and NCDO 619.

of NCDO 617. Extracts of NCDO 619 always showed two equally distinct components.

Although the intensity of the two LDH components varied between the strains, the migration distances were the same. When FDP was omitted from the developing solution there was no LDH activity, and therefore both components are FDP activated. It is not known 
whether these strains contain two different LDHs or whether the two components are different molecular forms of the same enzyme. Double banding was not observed after electrophoresis of extracts of strains of other species of group N streptococci.

Other differences between the LDHs of the various species were found when enzyme activity in relation to several variables was examined. The LDHs of $S$. lactis and $S$. cremoris were active at both pH 7.0 and 5.5. Earlier, Jonas et al. (7) observed the broad $\mathrm{pH}$ range at which the LDH of $S$. cremoris was active. The LDHs of S. lactis and S. cremoris are also characterized by having a low requirement for FDP, and enzyme activity was not greater with $500 \mu \mathrm{M}$ than with $25 \mu \mathrm{M}$ even at low concentrations of pyruvate $(0.5 \mathrm{mM})$ (Table 2$)$. On the other hand, the $\mathrm{LDH}$ of $\mathrm{S}$. raffinolactis had low activity at $\mathrm{pH}$ 7.0, which activity more than doubled at $\mathrm{pH}$ 5.5. At $\mathrm{pH} 7.0$ the $\mathrm{LDH}$ activity faded quickly when the concentration of either pyruvate or FDP was reduced. At $\mathrm{pH} 5.5$ the $\mathrm{LDH}$ of $S$. raffinolactis was more sensitive to a decrease in pyruvate concentration than the LDH of the other species of group $\mathbf{N}$ streptococci. At low pyruvate concentrations a high level of FDP was required.

The LDH of $S$. raffinolactis was inhibited by lower concentrations of phosphate than the $\mathrm{LDH}$ of the other species of group $\mathrm{N}$ streptococci (Table 3).

The properties of the LDHs of $S$. lactis and $S$. cremoris suggest that these species may have the same LDH but that the enzyme in S. raffinolactis is significantly different. Similar differences between FDP-activated LDHs of two spe- cies have been found by Hensel et al. (6) when working with Lactobacillus casei and Lactoba. cillus curvatus.

The relationship between $S$. raffinolactis and other streptococci as estimated by DNA homology is shown in Table 4. De Ley et al. (2) found that the reduction in optical density of DNA renaturation curves was straight for some $40 \mathrm{~min}$ after the reaction started. In the present experiments, even with DNA sheared in a French pressure cell as recommended by De Ley, renaturation curves were not straight and the renaturation rate was very slow. Needle-sheared DNA seemed more satisfactory, and the tech-

TABLE 3. Effect of phosphate on the activity of the LDHs of some group $N$ streptococci ${ }^{a}$

\begin{tabular}{|c|c|c|c|c|c|c|c|c|}
\hline \multirow{4}{*}{$\begin{array}{c}\text { NCDO } \\
\text { no. }\end{array}$} & \multicolumn{8}{|c|}{$\Delta \mathrm{OD}$ at $1 \mathrm{~min}(\%)$} \\
\hline & \multicolumn{4}{|c|}{ pH 7.0} & \multicolumn{4}{|c|}{ pH 5.5} \\
\hline & \multicolumn{2}{|c|}{$500^{b}$} & \multicolumn{2}{|c|}{50} & \multicolumn{2}{|c|}{500} & \multicolumn{2}{|c|}{50} \\
\hline & $20^{c}$ & 10 & 10 & 5 & 20 & 10 & 10 & 5 \\
\hline 712 & 83 & 88 & 28 & 66 & 35 & 85 & 8 & 42 \\
\hline 1007 & 68 & 83 & 14 & 66 & 47 & 85 & 13 & 66 \\
\hline 924 & 57 & 70 & 20 & 74 & 42 & 78 & 14 & 64 \\
\hline 617 & 0 & 27 & 0 & & 0 & 52 & 8 & 19 \\
\hline 618 & 31 & 49 & & & 20 & 56 & 5 & 36 \\
\hline 619 & 7 & 34 & 25 & 33 & 7 & 42 & 3 & 15 \\
\hline
\end{tabular}

${ }^{a}$ Conditions of the assay were the same as for Table 2. Phosphate $\left(\mathrm{PO}_{4}\right)$ was added to the assay solution as potassium phosphate buffer at the concentrations shown. Activity in the absence of phosphate was considered $100 \%$.

${ }^{b}$ FDP concentration (micromolar).

${ }^{c}$ Phosphate concentration (millimolar).

TABLE 2. Effect of pyruvate and FDP on the activity of the lactate dehydrogenase of some group $N$ streptococci $i^{a}$

\begin{tabular}{|c|c|c|c|c|c|c|c|c|c|c|c|}
\hline \multirow{4}{*}{ Species } & \multirow{4}{*}{$\begin{array}{c}\text { NCDO } \\
\text { no. }\end{array}$} & \multirow{4}{*}{$\begin{array}{c}{[(\Delta \mathrm{OD} \mathrm{pH}} \\
\begin{array}{c}7.0) /(\Delta \mathrm{OD} \mathrm{pH} \\
5.5)] \times 100\end{array} \\
3.3^{b} \\
500^{c}\end{array}$} & \multirow{4}{*}{ 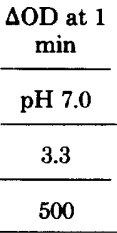 } & \multicolumn{8}{|c|}{$\Delta \mathrm{OD}$ at $1 \mathrm{~min}(\%)$} \\
\hline & & & & \multicolumn{4}{|c|}{ pH 7.0} & \multicolumn{4}{|c|}{ pH 5.5} \\
\hline & & & & \multicolumn{2}{|c|}{3.3} & \multicolumn{2}{|c|}{0.5} & \multicolumn{2}{|c|}{3.3} & \multicolumn{2}{|c|}{0.5} \\
\hline & & & & 500 & 25 & 500 & 25 & 500 & 25 & 500 & 25 \\
\hline S. lactis & 712 & 115 & 0.337 & 100 & 89 & 38 & 24 & 100 & 108 & 43 & 45 \\
\hline $\begin{array}{l}\text { S. lactis subsp. } \\
\text { diacetylactis }\end{array}$ & 1007 & 127 & 0.276 & 100 & 109 & 32 & 30 & 100 & 102 & 38 & 36 \\
\hline S. cremoris & 924 & 106 & 0.338 & 100 & 98 & 37 & 36 & 100 & 92 & 41 & 34 \\
\hline \multirow[t]{3}{*}{ S. raffinolactis } & 617 & 234 & 0.191 & 100 & 0 & 0 & 0 & 100 & 96 & 31 & 14 \\
\hline & 618 & & 0.215 & 100 & 11 & 8 & 0 & 100 & 87 & 13 & 5 \\
\hline & 619 & 240 & 0.153 & 100 & 3 & 0 & 0 & 100 & 100 & 10 & 8 \\
\hline
\end{tabular}

${ }^{a} \mathrm{LDH}$ activity was measured by the decrease in optical density $(\triangle \mathrm{OD})$ at $340 \mathrm{~nm}$ in $1 \mathrm{~min}$ at $30^{\circ} \mathrm{C}$. The assay solution contained $0.067 \mathrm{M}$ Tris-chloride buffer ( $\mathrm{pH} 7.0$ ) or $0.067 \mathrm{M}$ acetate buffer (pH 5.5) and $0.15 \mu \mathrm{M} \mathrm{NADH}$. Pyruvate and FDP were used at the concentrations shown. The reaction was started by adding $0.02 \mathrm{ml}$ of a solution of freeze-dried cell extract to $1.0 \mathrm{ml}$ of assay solution.

${ }^{b}$ Pyruvate concentration (millimolar).

${ }^{c}$ FDP concentration (micromolar). 
TABLE 4. Relationship between strains of streptococci calculated from $D N A$ renaturation rates

\begin{tabular}{lrc}
\hline \multicolumn{1}{c}{ Species } & $\begin{array}{c}\text { NCDO } \\
\text { no. }\end{array}$ & $\begin{array}{c}\text { Hybridi- } \\
\text { zation of } \\
\text { DNA (\%) }\end{array}$ \\
\hline S. lactis $\times$ S. cremoris & $2031 \times 924$ & 91 \\
S. lactis $\times$ S. raffinolactis & $2031 \times 617$ & 36 \\
S. lactis $\times$ S. raffinolactis & $2031 \times 619$ & 43 \\
S. cremoris $\times$ S. raffino- & $924 \times 617$ & 36 \\
$\quad$ lactis & & \\
S. raffinolactis $\times S$. raffi- & $619 \times 617$ & 98 \\
$\quad$ nolactis & & \\
\hline
\end{tabular}

nique was tested by using DNA from Leuconostoc strains that had been used in previous hybridization studies (5). It was found that the larger DNA fragments obtained by using a syringe needle gave a reasonable change in optical density, and by using the initial rate of renaturation the relationships could be calculated. Test runs with several strains gave results in agreement with those obtained earlier with labeled DNA.

The results in Table 4 show that $S$. raffinolactis is not closely related to either $S$. lactis or $S$. cremoris. The close relationship between the last two species was especially noteworthy. This observation needs confirmation with other strains before any conclusions can be drawn.

The newly discovered properties of NCDO 617, NCDO 618, and NCDO 619 confirm the earlier belief that these strains are not members of either $S$. lactis or $S$. cremoris. None of the strains examined by Orla-Jensen and Hansen was available for direct comparison. The properties that they give and the sources of their strains show that their strains might well be related to NCDO 617, NCDO 618, and NCDO 619 . The properties of several more strains were given by Garvie in 1953 (3). Not all of these ferment raffinose, but at the time it was felt that all the strains belonged to a single species. The only three strains to be kept all fermented raffinose.

\section{REPRINT REQUESTS}

Address reprint requests to: Dr. Ellen I. Garvie, National Institute for Research in Dairying, Shinfield, Reading, RG2 9AT, England.

\section{LTERATURE CITED}

1. De Ley, J. 1969. Reexamination of the association between melting point, buoyant density, and chemical base composition of deoxyribonucleic acid. J. Bacteriol. 101:733-754.

2. De Ley, J., H. Cattori, and A. Reynearts. 1970. The quantitative measurement of DNA hybridization from renaturation rates. Eur. J. Biochem. 12:329-372.

3. Garvie, E. I. 1953. Some Group N streptococci 1solated from raw milk. J. Dairy Res. 20:41-44.

4. Garvie, E. I. 1969. Lactic dehydrogenases of strains of the genus Leuconostoc. J. Gen. Microbiol. 58:85-94.

5. Garvie, E. I. 1976. Hybridization between the deoxyribonucleic acids of some strains of heterofermentative lactic acid bacteria Int. J. Syst. Bacteriol. 26:116-122.

6. Hensel, R., U. Mayer, K. O. Stetter, and O. Kandler. 1977. Comparative studies of lactic acid bacteria. 1 Purification and kinetics of the allosteric L-lactate dehydrogenase from Lactobacillus casei ssp. casei and Lactobacillus curvatus. Arch. Microbiol. 112:81-93.

7. Jonas, H. A., R. F. Anders, and G. R. Jago. 1972. Factors affecting the activity of the lactate dehydrogenase of Streptococcus cremoris. J. Bacteriol. 111:397-403.

8. Marmur, J. 1961. A procedure for the isolation of deoxyribonucleic acid from microorganisms. J. Mol. Biol. 3:208-218.

9. Marmur, J., and P. Doty. 1962. Determination of the base composition of deoxyribonucleic acid from its denaturation temperature. J. Mol. Biol. 5:109-118.

10. Marmur, J., S. Falkow, and M. Mandel. 1963. New approaches to bacterial taxonomy. Annu. Rev. Microbiol. 17:329-372.

11. Orla-Jensen, A. D., and P. A. Hansen. 1932. The bacteriological flora of spontaneously soured milk and of commercial starters for butter making. Zentralbl. Bakteriol. Parasitenkd. Infektionskr. Hyg. Abt. 2 86:6-29.

12. Swartling, P. F. 1951. Biochemical and serological properties of some citric acid fermenting streptococci from milk and dairy products. J. Dairy Res. 18:256-267. 